\title{
NRP1 Gene
}

National Cancer Institute

\section{Source}

National Cancer Institute. NRP1 Gene. NCI Thesaurus. Code C24642.

This gene is involved in a variety of cellular processes vital for survival and angiogenesis. 